\title{
RELIGION AS A DETERMINANT OF CHILD WELFARE IN CUSTODY CASES IN MALAYSIA AND CLASSICAL ISLAMIC LAW: A COMPARATIVE OVERVIEW
}

\author{
Mohamed Azam Mohamed Adil* \\ Rafeah Saidon**
}

\begin{abstract}
It is paramount to consider the welfare of a child when determining the custody of a child. However, in the event of a parent's conversion to Islam, the issue of religion also arises, i.e. whether the religion of a parent is considered the main factor or one of several factors in determining the interests of the child. In Malaysia, since both Islamic and civil law recognise conversion as grounds for divorce, the question concerning the custody of children and the determinants of religion for the best interest of children will be the main issue. This research aims to examine the significance of religion in determining the welfare of children in custodial dispute cases and to search for possible solutions from the perspective of Islamic jurisprudence relating to custodial conflict upon conversion of one spouse to another religion, particularly in a multiracial country like Malaysia. Our findings show that religion is the primary criterion in determining the welfare of children in custody cases from the classical Islamic point of view. However, Islamic law also offers various other solutions if there is a conflict involving non-Muslim parents.

Keywords: child welfare, custody, conversion, religion, civil court, Syariah court.
\end{abstract}

\section{Introduction}

Child custody refers to the upbringing of children, which includes the protection, love, care, education, sheltering and management of the child. ${ }^{1}$ Generally, in determining the legal custodian of a child, the court will ensure that the child's welfare is protected. In Malaysia, however, child custody is governed by two different laws for non-Muslims and Muslims, namely the Law Reform (Marriage and Divorce) Act of 1976 (hereinafter called LRA 1976) and the Islamic Family Law Enactment (of the respective states) or Act (for the Federal Territories) respectively. There are also two different courts dealing with this issue, i.e. civil and Shariah courts. Problem therefore arise when one of the spouses in a marriage converts to Islam because conversion is recognised as one of the 
grounds for dissolving a marriage by both the LRA 1976 and the Islamic Family Law/Enactment. Both judicial systems in Malaysia have jurisdiction on this issue whenever one of the parties is Muslim. The dissolution of marriage for Muslims is governed by the Shariah Court, while for the non-Muslim it will be under the Civil Court. As a result of law and jurisdictional conflicts, there are certain matters consequential to the divorce that provide different remedies, which include division of matrimonial assets, maintenance of children, custody and guardianship of children.

In determining the custody of a child, both Islamic law and civil law agree that the interest or welfare of the child is the paramount consideration. Factors that are taken into consideration in determining the interests of the child are, to a certain extent, common to both Islamic law and Civil law except in the matter of religion. Thus, both Islamic and Civil law consider age and gender of the child, wishes of the child (if the child is of an age to express independent opinion) ability to bring up the child and conduct of the parties. ${ }^{2}$ However, when a parent in the marriage converts, the question arises whether the religion of the parents or the parties involved is the only factor or only one factor (even if it is the main factor) in determining the interest of the child.

Although extensive research has been done on the issue of custody in Malaysia, no single study has comprehensively discussed religion as a determinant of child welfare in custodial dispute cases involving conversion of parents from the perspective of Islamic jurisprudence. Research by Yee (2014) and Lin (2013), for example, pointed out the contradictory rulings by the Civil and Shariah Courts in the case of child custody and commented that the parallel legal system in Malaysia complicates matters of justice. ${ }^{3}$ It has been argued that this dual system enables a spouse who contracted a civil marriage to convert to Islam and use the Shariah court as a means of claiming custody of children and evading financial responsibilities imposed by the other spouse under the civil law. For that reason, the International Institute of Advanced Islamic Studies (IAIS) Malaysia has proposed policy reforms relating to conversion in Malaysia. ${ }^{4}$ Among the recommendations made are, firstly, to ensure that the issue of conversion does not get in the way of making a decision on child welfare matters and custodial responsibilities of the disputing parents and, secondly, to amend section 51 of the LRA $1976 .{ }^{5}$ Thirdly, to establish a special branch of the judiciary with mixed jurisdiction, where both Shariah and Civil law judges sit and adjudicate issues of conversion and religious identity of the child. From the Islamic jurisprudential context, Che Soh \& Abdul Hak have examined the application of maslahah (interest) in custody cases, particularly in Shariah Court practices. ${ }^{6}$ Their findings have shown that maslahah is highly considered particularly when it relates to a child's interest. 
In light of the above issues, this research aims, firstly, to examine the significance of religion in determining the welfare of a child in custody cases. It then, secondly, aims to search for possible solutions to custodial conflict upon conversion of one spouse to another religion, particularly in a multi-religious country like Malaysia, from the perspective of Islamic jurisprudence.

\section{Methodology}

This research employs a qualitative method. Library research is used to obtain the data, itself derived from a plethora of references including Quranic verses, Prophetic traditions, the stories of the companions, books, journal articles and websites. In maintaining its relation with Islamic jurisprudence, this research draws insights from the earlier works of classical Muslim jurists who provided information related to the area of discussion. The current laws are also analysed, particularly the Islamic Family Law (Federal Territories) Act 1984, the Islamic Family Law (Selangor) Enactment 2003 (IFLS 2003) and related administrative procedures representative of other States in Malaysia. The Federal Territories are selected as they are the capital of Malaysia and directly administered by the federal government, whereas Selangor is under State's government. For purposes of this legal discussion, legal and textual approaches are used in which the classical texts, as well as the laws, are analysed in such a way as to highlight the previous rulings relating to custody. The discussion also examines the relevant case law to identify the judicial approaches towards custodial conflicts.

\section{Significance of Religion in Custody}

In Islamic law, it was agreed by all Muslim jurists that when a marriage is dissolved, the right of custody of an infant will be given to the mother. This is a prerogative right of the mother, since the mother is naturally not only more tender, but also better qualified to cherish a child during infancy. ${ }^{7}$ Furthermore, a mother is more compassionate than the father when dealing with children. She also normally spends more time at home; the mother is the one who will breastfeed the child and the one who knows better about the child in terms of education and upbringing. ${ }^{8}$ The mother and her female ancestors are preferred as custodians for the sole purpose of serving the best interests of the child.

The Muslim jurists conclude that the custodial parent is not only responsible for the daily care and control of the child; he or she is also responsible for deciding all matters which the child cannot decide for itself especially with regards to upbringing and education. ${ }^{9}$ This principle has been adopted by Islamic Family Law Act/Enactments in Malaysia. For example, in section 
82(1) of the Islamic Family Law (Selangor) Enactment 2003 (IFLS 2003), it is provided:

Subject to section 83 , the mother shall be of all persons the best entitled to the custody of her infant children during the connubial relationship as well as after its dissolution.

Meanwhile, section 82(2) of IFLS 2013 lists in order of preference all other persons capable of taking custody, in case the mother is disqualified under Hukum Syarak (Islamic law) from having the right of custody of her children. However, at the end of the section is the condition that the custody of such another person not negatively affect the welfare of the child. To make sure that the interests of the child are preserved, the Shariah Court is also empowered to make order for custody. For example, the court may at any time choose to place a child in the custody of any one of the persons mentioned in the list or to place the child in the custody of any other person or any association for the purpose of maintaining the welfare of the child. In determining the welfare of the child, the interests of that child should be given priority over the interests of the parents or the other parties involved. In other words, the interests of the child will always prevail over others. ${ }^{10}$

Religion is also an important criterion to be considered in determining child custody. Ibn Qudamah, a well-known Hanbali scholar of the $12^{\text {th }}$ century, stressed the importance of religion in the issue of custody. He said that "custody is aimed at looking after the child, so it should not be given in a way that will be detrimental to his welfare and his religious commitment." by 'Abd. Al-Hamid b. Ja'far, it is said that Rafi' ibn Sinan embraced Islam but his wife refused to do so. She came to the Prophet and said:

"My daughter is weaned or about to wean". Rafi' said: "My daughter". The Prophet said to him: "Be seated on a side". And he said to them: "Call her". The girl inclined to her mother. The Prophet said: "O Allah! Guide her." The daughter inclined to her father and he took her away. ${ }^{12}$

The above hadith shows that the Prophet did not deprive the non-converted mother from the opportunity of gaining custodial rights over her daughter. However, the Prophet indirectly indicated his preference towards the Muslim father by invoking the prayer "O Allah! Guide her" when the child demonstrated an inclination towards the mother. This episode indicates that the Prophet preferred the child to stay with the Muslim father for fear that the child would be influenced by the non-Muslim mother in regards to her faith. ${ }^{13}$

However, Muslim jurists have dealt with this issue in different ways. According to the Shafi'i and Hanbali schools of law, the custodian must profess 
the religion of Islam, otherwise he or she does not have the actual custody of the child. ${ }^{14}$ According to Sayyid Sabiq, this view is based on the Qur'anic verse:

And never will Allah grant to the unbelievers a way (to triumph) over the believers. ${ }^{15}$

Notably, the above verse hints that if a child is given to a non-Muslim custodian, the latter would influence the child's belief and the child would not be brought up according to the religion of Islam. ${ }^{16}$ The preservation of a child's religion proceeds with the concept of maqāșid al-sharī 'ah in Islam. This concept refers to the objectives of Shariah in implementing laws and policies in all aspects of life, including family matters. These objectives consist of protecting the five essential values of religion, life, intellect, lineage and property. Any measure which secures these values falls within the scope of mașlahah, and anything which violates them is mafsadah (evil), the prevention of which is also maslahah. ${ }^{17}$ Since religion is the first value that should be preserved in administering child custody, efforts should be taken to comply with this requirement.

On the other hand, in the Hanafi and Maliki schools, professing the religion of Islam is not a requirement for being a custodian. Thus the non-converted parent will be entitled to the right of custody of their children. However, the Hanafi and Maliki schools have laid down certain restrictions. For example, the custodian should not influence their children in matters pertaining to religious belief, except for Islam. Other restrictions include prohibition from taking children to church, from teaching them a religion other than Islam, and from asking them to eat pork or to consume alcohol. ${ }^{18}$

The significance of Islamic religion in custody cases can be seen in the implementation of custodial laws in some Muslim countries which allow nonMuslim parents to become custodians. For example, article 62 of the Algerian Code of Personal Status, 1984 (amended 2005) states the condition that the non-Muslim mother should bring up the child in the faith of Islam. Article 192 of the Kuwaiti Code of Personal Status, 1984 provides that the non-Muslim custodian shall be entitled to the custody of the child until the child starts to understand about religion, or until it is feared that he or she may become familiar with faiths other than Islam, even though the child does not understand about religion. The child shall not remain with such a custodian after he or she has reached the age of five. Article 59 of the Tunisian Code of Personal Status 1956 (amended 1993) and Article 108 of the Moroccan Family Code (Moudawana) 2004 state in almost identical terms that non-Muslim mother could be given custody but will lose such rights after the child has reached five years of age, unless there is no fear that the child will be brought up according to a religion other than Islam. ${ }^{19}$ 
Malaysia, on the other hand, has adopted a strict approach to the custody issue. Section 82 of the Islamic Family Law (Federal Territories) Act 1984 (hereinafter called IFLA 1984) states that the first qualification necessary for custody is that the person must be a Muslim. It is also stated in section 83 that the right of custody is lost if the custodian becomes a murtad (apostate). Such laws are in line with the views of al-Mawardi, a great Muslim scholar of the Shafi'i school, on important duties of Islamic government to preserve religion. ${ }^{20}$ Similarly, El-Awa stated that the purpose of an Islamic state is to establish al-din (the faith) and to secure the interests of the ruled. ${ }^{21}$ The establishment of faith, then, is a fundamental goal which the Islamic state has to prioritise. Since Islam is understood to be al-din which means a complete way of life for humanity, so the state has to render help to Muslim society in order to achieve this form of spirituality.

\section{Solutions from the Islamic Jurisprudential Context for Custodial Conflict}

As a plural society, conversion from one faith to another in Malaysia is inevitable. In the case of a husband's or wife's conversion, prevailing issues on legal implications, such as custody of a child, remain unresolved. For example, regarding this matter, the Civil Court in Malaysia has adopted several different approaches.

For example, in the case of Sharmala Sathiyaseelan v Dr. Jeyaganesh $C$ Mogarajah \& Anor ([2004] 3 CLJ 516), the court gave joint custody to both parents, even though one of the parties was a non-Muslim. In this case, Sharmala and Dr Jeyaganesh were married on 5 November 1998 according to Hindu rites and their marriage was registered under the LRA 1976. Four years later, the husband embraced Islam and also converted their sons. Sharmala had applied to the High Court for custody of the children. In the judgement, Justice Faiza Thamby Chik gave joint legal custody to the parents. However, actual custody, i.e. the care and control of the children, daily care and responsibility for looking after them, was given to the mother. In addition, the judge put the caveat that the children were mualaf (Muslim converts) and the mother would lose the right to actual custody if there were reasonable grounds to believe that she would influence the children's present religious beliefs, for example by teaching them the articles of her faith or making them eat pork. Even though this judgment conformed to Islamic law, the judge unfortunately did not suggest or propose any guidelines on how to ensure that the non-converted mother followed such restrictions.

However, this judgment is inconsistent with Justice Chin's reasoning in Chang Ah Mee v Jabatan Hal Ehwal Agama Islam ([2003] 1 CLJ 458), that the 
mother who had custody of an infant whose father converted to Islam should not be compelled to send the infant to Islamic religious school, noting that the Quran stated that there shall be no compulsion in religion (al-Baqarah 2:286).

In the case of Indira Gandhi Mutho v. Pengarah Jabatan Agama Islam Perak \& Ors. ([2013] 7 CLJ 82), the estranged husband Mohd Ridzuan Abdullah had unilaterally converted their three children (aged 12 years, 13 years and 18 months) without the consent of his non-converted wife. This may have been because, by converting the children, it was easier for Mohd Ridzuan to get custody from the Shariah court. Nevertheless, the High Court held that the conversion was unlawful and unconstitutional as it was done without the mother's consent, breaching Articles 3, 5 and 11 of the Federal Constitution. On appeal, however, the Court of Appeal, in a 2-1 majority dismissed this judgment by making that matters relating to Islam fall exclusively under the jurisdiction of the Shariah Courts. ${ }^{22}$ Similarly, in Saravanan Thangathoray v. Subashini Rajasingam \& Another ([2007] 2 CLJ 45), the Court of Appeal, by a majority, dismissed the wife's appeal for an injunction restraining the husband from converting either child of the marriage to Islam.

Cases like Indira Gandhi and Subashini represent the dominant trend in Malaysia, thereby causing unease in the country's multi-religious society. Indeed, the recent case of Viran Nagupan v Deepa Subramaniam ([2015] 3 MLJ 209) shows that some Malaysians are disappointed with the court's decisions. In this case, the Federal Court set aside the orders of the High Court and Court of Appeal with regard to custody. It granted custody of the couple's eight-year-old son to the father and eleven-year-old daughter to the mother. Interestingly, the court made the order after interviewing the children for forty minutes in chambers. This new approach taken by the Federal Court has been criticised on the basis that it was a last-minute decision. Interviewing the children in court before the custody order has been labelled improper and intimidating for the children. It is suggested that child psychologists and experts should be consulted to ensure that the children's best interests will be preserved. It is observed from the court cases that have been decided, that different judges have different opinions concerning custodial issues resulting from conversion. This will create tension and dissatisfaction in society, hence jeopardising the social fabric of Malaysia; multicultural and multireligious society.

In view of the cornucopia of custody issues mentioned above, Islam provides significant solutions to prevailing custodial conflicts. One of the clearer solutions from a Islamic jurisprudential context is the doctrine of siyassah shar'iyyah (Shariah-oriented policy). Ibn Qayyim defines it as measures that actually bring people closer to good and virtuous dealings, and prevent them from disruption on 
matters for which no specific ruling could be found in the Qur'an and the Sunnah of the Prophet..$^{23}$ In other words, this policy authorises the ruler to determine the manner in which the Shariah should be administered. Under this doctrine, the ruler or the government is deemed to take any discretionary measures, enact any rules and establish any policies which are considered in the best interests of the people, provided that no substantive principles of the Shariah are violated. ${ }^{24}$

With regard to custodial conflict, by applying siyäsah shar'iyyah, the government of Malaysia has been urged to be proactive in resolving the issue. One of the recommendations is setting-up a special bench of mixed jurisdiction where both Shariah and civil law judges sit and adjudicate disputed issues of conversion. The civil court will determine which case needs to be referred for adjudication to the court of mixed jurisdiction. It is also suggested that the law should stipulate that the court may issue a joint custody order specifying, among others, that the custodian should expose the child to religious education in both of the respective religions of his/her parents. The present practice of having a shared jurisdiction between two different courts of Civil and Shariah in handling mu'ámalat cases is a good example to be followed. Another suggestion is forming a Judicial Committee by the Conference of Rulers (Majlis Raja-Raja) which deals only with conversion cases..$^{25}$

The other solution from an Islamic jurisprudential context is the application of the maslahah (welfare) doctrine. This doctrine authorises the government to take necessary measures, including legislation, to attain the well-being of its citizens ${ }^{26}$ The State has the discretionary power to ascertain the ways and means that could bring maslahah to its citizens. Nonetheless, the State shall not take excessive actions which could lead to abuse of power. The power should, as suggested by Kamali, be governed by a set of principles according to which any action taken by the State must be precise and clearly aimed for the realisation of public interest. ${ }^{27}$

The doctrine of maslahah can also be referred to as any undefined yet beneficial approach taken for securing the interests of the public, and which has not been regulated by the Lawgiver and for which no textual authority can be found, whether to support, or reject its validity. ${ }^{28}$ In this regard, when the maslahah is identified and an explicit ruling in the Qur'an and Sunnah can not be found, necessary steps should be taken to secure it. Therefore, in the area of public interest, the state enjoys greater freedom and has discretion to introduce laws and policies and to adopt measures towards realisation of the public interest. This is justified by several verses of the Quran, including al-Anbiya' (21):107, Yunus (10):75, al-Haj (22):78, and al-Ma'idah (5):6 which all state that the purpose behind the revelation of the Shariah is to promote human welfare and to prevent prejudice and corruption in the world. 
With regard to custodial conflict, by applying maslahah, it is advisable for the Malaysian authorities not to confine themselves to one particular madhhab (school of law) and abandon the rest. Even evidence that has a great deal of influence within a particular madhhab must be carefully examined and the suitability of any fatwa (religious edict) based on it thoroughly assessed. The view of one madhhab might be appropriate to a specific context in a specific time, but it might not be replicated in other contexts. ${ }^{29}$ In the case of custodial conflict in Malaysia, since the country is a multiracial country, the opinion of Maliki and Hanafi schools should be taken into consideration instead of only that of Shafi' $i$ in order to maintain a harmonious relationship between parents. ${ }^{30}$ Thus, religion of the parties should not be the only factor in determining the custody of the child. All factors should be taken into consideration. Then the court will decide which parent will be given custody so that the welfare of the child will be protected. It is a duty of the Muslim parent who is not given the care and control of the child to portray a good image of Islam that can attract the child to the religion. ${ }^{31}$

Another solution available from Islamic jurisprudence is applying the concept of 'adalah (justice). As can be seen in more than a few verses in the Qur'an, including al-Nisa' (4):58-59 and al-Ma'idah (5):8, the practice of justice is one of the pivotal principles in Islamic governance. In Islam, justice applies to Muslims and non-Muslims. Human dignity and justice, social harmony and equitable treatment are meant not only for Muslims but for everyone. Indeed all human beings must be treated with dignity and justice. Law in Islam is meant to ensure people's welfare and peace corresponding to normal order in social relations. ${ }^{32}$ Thus, any proposed laws for custodial conflict in Malaysia must provide satisfactory solutions for the public and which are, at the same time, acceptable to both the Shariah and civil law.

\section{Conclusion and Recommendations}

In addressing the current problem of custodial conflict involving Muslim and non-Muslim parents, the renewal of Islamic jurisprudence must be taken into consideration, aiming to balance the dictates of foundational texts (the Qur'an and hadith) and the reality of society.

- Malaysian authorities should take a moderate approach when resolving the issue. Even though Shaf' $i$ is the official madhhab (school of thought) in Malaysia, views from other madhāhib must be carefully examined and the suitability of fatwa must be thoroughly assessed. No one madhhab is superior to another; Muslim scholars should not confine themselves, to one particular madhhab.

- For the welfare of the child, Islam recognises religion as a significant 
determinant. However, in a multiracial country such as Malaysia, different approaches should be taken by the authorities when handling the issue of child custody in mixed marriages.

- From the Islamic jurisprudence viewpoint, this research found significant principles available for the solution of custodial conflict, particularly when it involves conversion of parents, such as the principles of siyassah shar 'iyyah, mașlahah and 'adalah. All those principles are important and support and supplement each other.

- Religion should not be the only factor in determining the custody of a child. In cases where one party converts to Islam, our proposal is that all factors must be taken into consideration, and the court should decide which parent is given the custody so that the welfare of the child will be carefully protected.

\section{Notes}

* Mohamed Azam Mohamed Adil Deputy CEO, International Institute of Advanced Islamic Studies (IAIS) Malaysia, Jalan Elmu off Jalan Universiti, 59100 Kuala Lumpur/Associate Professor, Academy of Contemporary Islamic Studies (ACIS), Universiti Teknologi MARA Selangor, 40450 Shah Alam, Selangor (mazamadil@iais.org.my/mazamadil@hotmail.com).

** Rafeah Saidon Senior Lecturer, Academy of Contemporary Islamic Studies (ACIS), Universiti Teknologi MARA Selangor, 40450 Shah Alam, Selangor (rafeahsaidon@hotmail.com).

1. Roslina Che Soh \& Nora Abdul Hak, 'Application of Maslahah (Interest) in Deciding the Right of Hadanah (Custody) of a Child: The Practice in the Syariah Court in Malaysia,' Journal of Applied Sciences Research 7, no. 13 (2011). 2182-8.

2. Najibah Mohd.Zain, 'Harmonising the Conflicts in Family Related Disputes Upon Conversion of One Spouse to the Other Religion,' International Seminar On Syariah \& Common Law 2006, Seri Kembangan Hotel, Selangor, 20-21 September 2006, 3.

3. Chong Piu Yee, 'Islamisation in Malaysia: Shariah, Custody and Justice,' RSIS Commmentaries (2014), 1-2; Goh Siu Lin, 'Custodial Tussles and the Unilateral Religious Conversion of Children in Malaysia,' Family Law Newsletter (2013), International Bar Association Legal Practice Division, 66-8.

4. Mohamed Azam Mohamed Adil \& Ahmad Badri Abdullah, 'Penukaran Agama Kanak-Kanak: Isu dan Cadangan,' IAIS Malaysia Policy Issue Papers (2016); Mohamed Azam Mohamed Adil \& Rafeah Saidon, 'Penentuan Agama dan Hak Penjagaan Kanak-kanak Menurut Undang-undang Islam,' JAKIM (2014); Mohammad Hashim Kamali et al., 'Conversion in Malaysia: Issues and Reforms Proposals,' IAIS Malaysian Policy Issue Papers (2012). 
5. The LRA 1976 provides conversion to Islam as grounds for dissolving a marriage. It is stated in section 51(1) that "Where one party to a marriage has converted to Islam, the other party who has not converted may petition for divorce: Provided that no petition under this section shall be presented before the expiration of the period of three months from the date of the conversion." The wording of this section has raised a number of problems. This is because, according to the Act, it is not applicable to persons professing the religion of Islam. Thus section 51 is drafted in such a way that only the non-Muslim party to a marriage can file a petition for divorce based on conversion. It is suggested that "(1) Where one party to a marriage has converted to Islam-

(a) either party may petition for a divorce under this section or section 53; or

(b) both parties may petition for a divorce under section 52."

6. Che Soh \& Abdul Hak, 'Application of Maslahah'. supra 2182-8.

7. Burhanuddin al-Marghinani, The Hedaya: Commentary on the Islamic Laws, trans. Charles Hamilton, vol.1 (London: Kitab Bhavan, 1985), 386.

8. Sayyid Sabiq, Fiqh Sunnah, vol. 8, trans. Moh Thalib (Kuala Lumpur: Victory Agency, 1990), 162.

9. Ibid.

10. Abdullah Abu Bakar, 'Hak Hadhanah dan Pelaksanaannya,' in Manual UndangUndang Keluarga Islam, ed. Abdul Monir Yaacob and Siti Shamsiah Md Supi (Kuala Lumpur: IKIM, 2006), 123-34.

11. Ibn Qudamah al-Maqdisi, al-Mughni, Vol. 7 (Beirut: Dar al-Fikr, n.d.), 612,

12. Sabiq, 'Fiqh Sunnah,' 168.

13. Nuraisyah Chua Abdullah, Conversion to Islam, Effect on Status of Marriages and Ancillary Reliefs (Petaling Jaya, Malaysia: International Law Book Services, 2004), 42.

14. Abdul Rahman al-Jaziri, Kitāb al-Fiqh 'ala al-Madhāhib al-Arba'ah, vol. 4 (Beirut: Dar al-Fikr, 1986), 597.

15. Quran, (4):141.

16. Ariffin Mohamad, 'Hak Penjagaan Anak (Hadhanah) mengikut Undang-Undang Keluarga Islam,' in Manual Undang-Undang Keluarga Islam, ed. Abdul Monir Yaacob \& Siti Shamsiah Md Supi, (Kuala Lumpur: IKIM, 2006), 142.

17. Abu Hamid al-Ghazali, al-Mustasfa min 'ilm al-Ușūl, Vol. 1 (Beirut: Mu'assasah al-Risalah, 1997), 379; Abu al'Aynayn Badran, Ușūl al-Fīqh al-Islāmī (Iskandariah: Mu'assah Shabab al-Jami'ah, 1984), 211.

18. Al-Jaziri, Kitāb al-Fiqh, supra, 596-8; The Hedaya: Commentary on the Islamic Laws, Burhanuddin al-Marghinani, trans. Charles Hamilton, (vol. 1) (London: Kitab Bhavan, 1985), 389.

19. Jamal J. Nasir, The Islamic Law of Personal Status, $2^{\text {nd }}$ ed (London: Graham and Trotman, 1990), 128.

20. Abu'l-Hasan al-Mawardi, al-Ahkām al-Sulțaniyyah wa al-Wilāyat al-Din̄iyyah, (Beirut: Dār al-Kitāb al-'Arābi, 1990), 29.

21. Muhammad Selim El-Awa, On the Political System of Islamic State (Indianapolis, 1990). 76-7.

22. Wan Naim Wan Mansor, 'The Indira Ghandi Case and the Advocacy of Justice,' Islam and Civilisational Renewal 7, no. 1 (2016) 124-7.

23. Ibn Qayyim al-Jawziyyah, Al-Turūq al-Hukmiyyah fì al-Siyāsah Shar`ìyyah 
(Cairo: al-Mu'assah al-'Arabiyyah li al-Tiba’ah, 1961), 16.

24. Mohammad Hashim Kamali, 'Siyāsah Shar'̌̄yyah or Policies of Islamic Government,' The American Journal of Islamic Social Sciences 6, no. 1 (1989).

25. Mohamed Azam Mohamed Adil \& Ahmad Badri Abdullah, Penukaran Agama Kanak-Kanak, 13-5; Mohamed Azam Mohamed Adil \& Rafeah Saidon, Penentuan Agama, 24-5; Mohammad Hashim Kamali et. al, Conversion in Malaysia, 11-2.

26. Kamali, 'Siyāsah Shar' 'iyyah'.

27. Ibid.

28. Badran, Ușūl al-Fīqh al-Islami, 211.

29. Yasmin Hanani Mohd. Safian, 'The Contribution of Yusuf Qaradawi to the Development of Fiqh,' Electronic Journal of Islamic and Middle Eastern Law 4 (2016): 45-53.

30. Normi Abdul Malik, 'Hadhanah Menurut Undang-Undang Islam dan Pelaksanaannya Di Malaysia,' Jurnal Undang-Undang IKIM 8, no. 2 (2004): 52.

31. Najibah Mohd Zain, 'Harmonising the Conflicts', supra.

32. Kamali et. al, Conversion in Malaysia, 9. 